UDK 632.53

Naučni rad - Scientific paper

\title{
Impact of salinity on seed germination and early establishment of field dodder (Cuscuta campestris Yunck.)
}

\author{
Marija Sarić-Krsmanović, Ljiljana Radivojević, Jelena Gajić Umiljendić \\ Institute of pesticides and environmental protection, Belgrade, Serbia \\ e-mail: marijasaric.msaric@gmail.com
}

\begin{abstract}
The aim of this study was to determine the reaction of Cuscuta campestris Yunck. at different salt concentrations, due to the possibility of predicting its spread to areas with saline soils. Seeds of field dodder were placed in Petri dishes filled with $5 \mathrm{~mL}$ of salt solution with different concentrations of $\mathrm{NaCl}(5,10,20,40,80,160,320 \mu \mathrm{M})$. Only water was added to the control treatment. The number of germinated seeds was recorded daily (germination rate), and the final percentage of germination and seedling length were measured after 18 days. All of the experiments were carried out in the dark, in an incubator at $25^{\circ} \mathrm{C}$. Germination percentage was negatively affected by salt concentrations in Petri dishes. Increasing salt concentration tended to decrease the germination and seedling length. Final percentage of germination ranged from $0.0 \%$ (in 320 $\mu \mathrm{M} \mathrm{NaCl}$ ) to $82.1 \%$ (in $5 \mu \mathrm{M} \mathrm{NaCl}$ ), while it was $92.5 \%$ in the controltreatment. Seedling length ranged from $2.2 \mathrm{~cm}$ to $8.5 \mathrm{~cm}$ and germination rate ranged from 7.7 to 20.1 .
\end{abstract}

Keywords: field dodder, salt concentration, germination, seedling length.

\section{INTRODUCTION}

Broad geographic distribution and spectrum of hosts make field dodder, Cuscuta campestris, one of the most widespread and most harmful pests among flowering parasitic plants. Even though North America is assumed to be its place of origin, the species is cosmopolitan and very widespread in South America, Europe, Asia, Africa and Australia (Holm et al., 1997). Agriculturally, the most important Cuscuta species are C. campestris and C. pentagona, which show an almost worldwide distribution and have a wide spectrum of hosts. Field dodder (C. campestris) parasitizes many different plants, inducing negative impacts on the growth 
and yield of infested hosts and has significant effects on the structure and function of plant communities that are infested by this holoparasite (Press and Phoenix 2005; Albert et al., 2008). Species invasions are a principal component of global change, causing significant losses in biodiversity, as well as economic damage (D’Antonio et al., 2001). Large economic impacts are also associated with many invasive species, which can cause agricultural losses (Andow et al., 1990). Crop plants are usually exposed to different environmental stressors which limit their growth and productivity. Weed seeds are exposed to the same influences (such as temperature, light, $\mathrm{pH}$ and soil moisture), including the salt stress, which significantly affects their germination, growth and productivity (Chauhan et al., 2006; Nandula et al., 2006). Knowledge about the impact of salt on germination would be very helpful for understanding the potential for spread and invasiveness of field dodder species.

Predicting the seedling start and duration of early establishment can contribute to making better decisions for the control of field dodder (Berti et al., 1996) and facilitate the optimal timing of control practices (Grundy, 2003). Results on the effects of environmental factors on germination and early establishment can be very useful in that context. In this study, we evaluated the following questions: (1) Is germination of field dodder dependent upon salt concentration? (2) Is seedling length of field dodder dependent upon salt concentration?

\section{MATERIALS AND METHODS}

Field dodder seeds were collected at Popovici (Mladenovac) (W:7467846, E:4933974, alt. $215 \mathrm{~m}$ ) in September of 2011. The seeds were cleaned and stored in the laboratory in paper bags, at a temperature of 20 to $22^{\circ} \mathrm{C}$.

Seeds surface was sterilized with $15 \%$ sodium hypochlorite solution ( $\mathrm{NaOCl}$ ) for 5 minutes and then rinced three times with distilled water to avoid possible inhibition of germination due to fungal or bacterial toxins. Twenty disinfected seeds were placed into each Petri dish. Five $\mathrm{ml}$ of each solution of $\mathrm{NaCl}(5,10,20,40,80,160,320 \mu \mathrm{M})$ were also added to each dish and kept in an incubator in the dark (Binder CE) at $25 \pm 1^{\circ} \mathrm{C}$. Only water was added to the control. All the dishes were sealed with parafilm to avoid evaporation. Solutions were drained and replaced every second day in order to minimize changes in salinity due to evaporation. The number of germinated seeds was recorded daily (germination rate), and the final percentage of germination and seedling length were measured after 18 days. The experiment design was a randomized complete block with four replications, repeated twice and the data was combined for the analysis.

Data analysis. Data was analysed by a one-way analysis of variance (ANOVA) using STATISTICA 8.0. software package. When F values were statistically significant $(\mathrm{p}<0.05)$, the treatments were compared using the Fisher's Least Significant Difference (LSD) test. Also, germination rate (GR, sum of germinations per day) was calculated using the formula:

$\mathrm{GR}=\mathrm{n} 1 / \mathrm{t} 1+\mathrm{n} 2 / \mathrm{t} 2+\ldots .+\mathrm{nx} / \mathrm{tx}$,

where $n 1, n 2, \ldots . n x$ are the numbers of germinated seeds at times $t 1, t 2, \ldots . t x$, in days 


\section{RESULTS AND DISCUSSION}

Seed germination is dependent on various factors, including temperature, humidity, type of soil, seed size, dormancy, etc. (Benvenuti, 2007). Our data show that different salt concentration $(F=20.92 ; p<0.05)$ had a significant impact on the germination of field dodder seeds. Their germination at different salt concentrations between 5 and $320 \mu \mathrm{M}$ are presented in Figure 1a. Our data show that the highest total germination of field dodder seeds was in the control treatment (92.5\%). Conversely, germination was at its minimum when the salt concentration was $160 \mu \mathrm{M}(30.7 \%)$, while there were no seeds germinated in the highest salt concentration $(320 \mu \mathrm{M})$ (Figure 1a). Contrary to this, Frost et al. (2003) have found that germination of $C$. salina was not dependent on salinity, and thus zonation patterns of this parasite cannot be directly attributed to the effect of variation in salt concentration on seed emergence. Also, they have shown that salt-stunted host plants can function as surprisingly good hosts given their small size, a finding that matches field observations and reports of
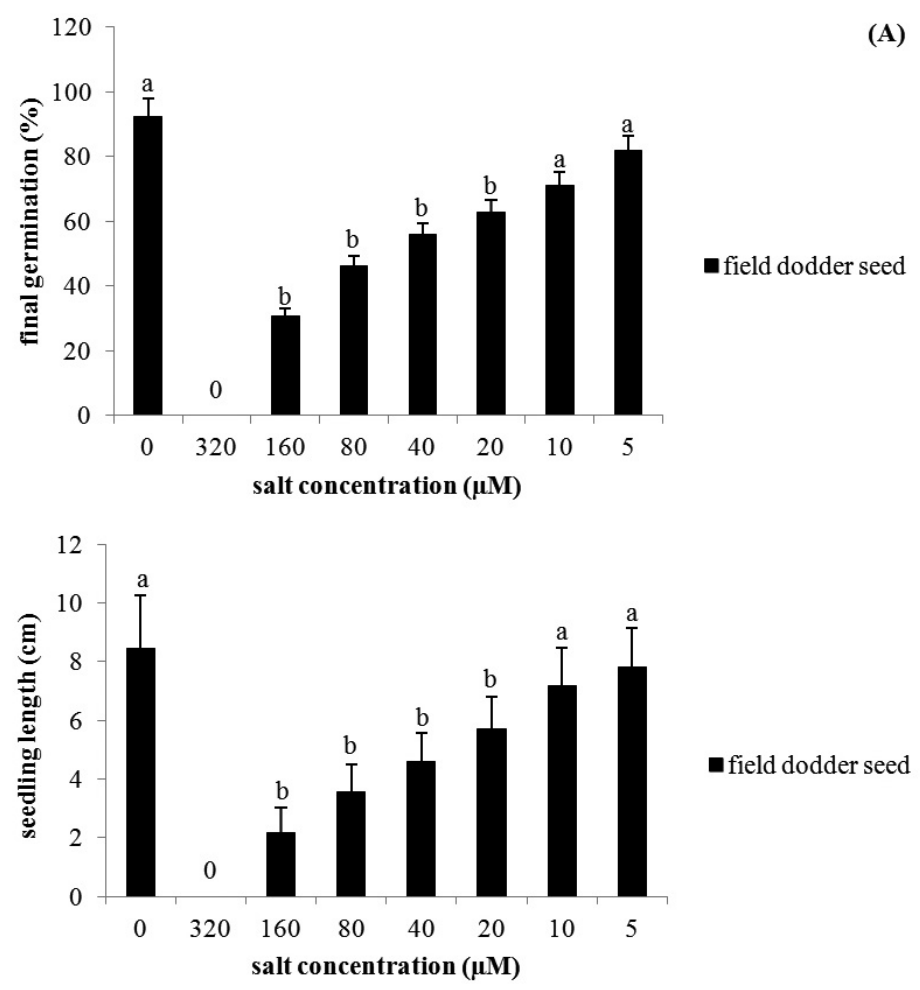

Figure 1. Final percentage of seed germination (\%) (A) and seedling length $(\mathrm{cm})(\mathrm{B})$ of field dodder at different salt concentration; $\mathrm{a}, \mathrm{b}-$ differences between treatments (LSD test, $\mathrm{p}<0.05$ )

Grafik 1. Procenat klijanja semena (\%) (A) i dužina klijanaca $(\mathrm{cm})(\mathrm{B})$ viline kosice pri različitim koncentracijama soli; $\mathrm{a}, \mathrm{b}$ - statističke ratlike između tretmana (LSD test, $\mathrm{p}<0.05$ ) 
luxuriant growth in moderately saline areas of salt marshes (Sanderson, 1998; Sanderson et al., 2000). Other field dodder species are hypothesized to have a preference for host species such as legumes and mints that have a high baseline amount of nitrogenous compounds (Salageanu and Fabian-Galan, 1968). Furthermore, Kelly (1992) has shown that some dodders have the ability to reject hosts with low nitrogen content. Therefore, although there is a growing consensus that Cuscuta species are not parasitic generalists (Kelly et al., 1988), results from Frost i sarl. (2003) suggest that the perceived specialization in some members of the genus is instead partly dictated by underlying environmental conditions that affect the susceptibility of specific host species.

The growth of weed seedlings is affected by various factors, such as temperature, light, seed depth in the soil, seed storage conditions, soil bacteria and seed vigour (Bekker et al., 1998). The effects of different salt concentration on seedling length of field dodder seeds in our experiment are presented in Figure 1b. The length of seedlings on the final day of the experiment was highest in the control treatment $(8.5 \mathrm{~cm})$. Contrary to this, seedlings length was lowest $(0.00-2.2 \mathrm{~cm})$ at $320 \mu \mathrm{M}$ and $160 \mu \mathrm{M}$ of salt concentrations. Statistically significant differences $(p<0.05)$ between control and the treatments on germination and seedling length were not detected only in treatments with lower salt concentration $(5 \mu \mathrm{M}$ and $10 \mu \mathrm{M})$ (Figure la,b).

Germination rates were calculated based on the daily recorded data for germinated field dodder seeds (Table 1), thus showing the seed germination dynamic. The highest germination rate was detected in the control treatment (20.1), while the minimum rates (0.00-7.7) were found at $320 \mu \mathrm{M}$ and $160 \mu \mathrm{M}$ of salt concentration.

Table 1. Impact of different salt concentration on germination rate (no. day ${ }^{-1}$ ) of field dodder Tabela 1. Uticaj različitih koncentracija soli na stopu klijanja viline kosice

\begin{tabular}{lllllllll}
\hline Salt concentration $(\mu \mathrm{M})$ & 0 & 320 & 160 & 80 & 40 & 20 & 10 & 5 \\
\hline Germination rate & 20.1 & 0.0 & 7.7 & 10.3 & 13.6 & 15.1 & 18.8 & 18.9 \\
\hline
\end{tabular}

In agricultural practice, the primary and permanent source of new weed growth is the seed bank in the soil. Many biological characteristics of the seeds and the processes normally occurring in them help plants maintain a permanent reserve of seeds in the soil and lead to the ensuing weediness of agricultural fields. Better understanding of seed ecology can be helpful in predicting the potential for the spread of weed species, in predicting their invasiveness, and in developing more effective weed management strategies. Seed germination is a key factor in determining the success of a weed species in an agroecosystem, and several environmental characteristics, such as temperature, light, $\mathrm{pH}$, soil moisture and salt concentration, are known to affect seed germination. Our results are a contribution to better understanding field dodder germination and emergence, and can be useful in developing programmes for the control of this species. 


\section{ACKNOWLEDGEMENT}

We thank the Ministry of Education, Science and Technological Development of the Republic of Serbia for funding this study, Projects III46008 and TR31043.

\section{REFERENCES}

Albert, M., Belastegui-Macadam, X., Bleischwitz, M., Kaldenhoff, R.: Cuscuta spp: parasitic plants in the spotlight of plant physiology, economy, and ecology. Progress in Botany, 69, 267-277, 2008.

Andow, D. A., Kareiva, P. M., Levin, S. A., Okubo, A.: Spread of invading organisms. Landscape Ecology, 4, 177188, 1990.

Benvenuti, S.: Natural weed seed burial: effect of soil texture, rain and seed characteristics. Seed Science Research, 17, 211-219, 2007.

Berti, A., Dunan, C., Sattin, M., Zanin, P., Wesra, G.: A new approach to determine when to control weeds. Weed Science, 44, 496-503, 1996.

Chauhan, B. S., Gil, G., Preston, C.: Factors affecting seed germination of annual sowthistle (Sonchus oleraceus) in Southern Australia. Weed Science, 54, 854-860, 2006.

D’Antonio, C., Meyerson, L. A., Denslow, J.: Exotic species and conservation. In: Soule ME, Orians GH (Eds.). Conservation Biology: Research Priorities for the Next Decade. Island, Washington DC USA pp 59-80, 2001.

Frost, A., Lopez-Gutierrez, J. C., Purrington, C. B.: Fitnesse of Cuscuta salina (Convolvulaceae) parasitizing Beta vulgaris (Chenopodiaceae) grown under different salinity regimes. American Journal of Botany, 90, 7, 1032-1037, 2003.

Grundy, A. C.: Predicting weed emergence: a review of approaches and future challenges. Weed Research, 43, 1-11, 2003.

Holm, L., Doll, J., Holm, E., Pancho, J. V., Herberger, J. P.: World weeds: Natural histories and distribution. New York: J. Wiley, 1997.

Kelly, C. K., Venable, D. L., Zimmerer, K.: Host specialization in Cusctua costaricensis: an assessment of host use relative to host availability. Oikos, 53, 315-320, 1988.

Kelly, C. K.: Resource choice in Cuscuta europaea. Proceedings of the National Academy of Sciences, USA, 89, 12 194-12 197, 1992.

Nandula, V. K., Eubank, T. W., Poston, D. H., Koger, C. H., Reddy, K. N.: Factors affecting germination of horseweed (Conyza canadensis). Weed Science, 54, 898-902, 2006.

Press, M. C., Phoenix, G. K.: Impacts of parasitic plants on natural communities. New Phytology, 166, 737-751, 2005.

Salageanu, N., Fabian-Galang, G.: Studies on the nutrition of Cuscuta sp. Revue Roumaine de Biologie (Serie de Biologie Vegetale), 13, 321-324, 1968.

Sanderson, E. W., Ustin, S. L., Foin, T. C.: The influence of tidal channels of the distribution of salt marsh plant species in Petaluma Marsh, CA, USA. Plant Ecology, 146, 29-41, 2000.

Sanderson, E. W.: Intrepretation and modelling of landscape pattern in ecological remote sensing data: three examples. Ph.D. dissertation, University of California, Davis, California, USA, 1998. 


\section{Uticaj saliniteta na klijavost i početni rast klijanaca viline kosice (Cuscuta campestris Yunck.)}

\section{REZIME}

Cilj ove studije je bio da se utvrdi klijanje semena Cuscuta campestris pri različitim koncentracijama soli, što bi moglo ukazati na mogućnost predviđanja njenog širenje na područja sa zaslanjenim zemljištem. Semena viline kosice su stavljena u Petri posude sa po $5 \mathrm{~mL}$ rastvora sa različitim koncentracijama $\mathrm{NaCl}(5,10,20,40,80,160,320 \mu \mathrm{M})$. Voda je služila kao kontrolna varijanta. Broj klijalih semena beležen je svakodnevno (stopa klijanja), a konačni procenat klijavosti i dužine klijanaca su izmereni nakon 18 dana. Svi tretmani su izvedeni u mraku u inkubatoru na $25^{\circ} \mathrm{C}$. Povećanjem koncentracije soli, uočena je tendenciju smanjenja klijavosti kao i dužine klijanaca. Procenat klijanja kreće se od 0,0\% (u $320 \mu \mathrm{M} \mathrm{NaCl}$ ) do 82,1\% (u $5 \mu \mathrm{M}$ $\mathrm{NaCl}$ ), dok je u kontrolnoj varijanti bio $92,5 \%$. Dužina klijanaca varira od 2,2 cm do $8,5 \mathrm{~cm}$, a stopa klijanja se kreće od 7,7 do 20,1.

Ključne reči: vilina kosica, koncentracija soli, procenat klijanja, dužina klijanaca. 